\title{
Exploring the Path of Teaching Reform in General Courses of Basic Music Theory in Colleges and Universities from the Perspective of "Curriculum Ideological and Political"
}

Yixian Jiang

Guangzhou College of South China University of Technology, Guangzhou 510800, Guangdong, China. E-mail: jyx202021@163.com

Abstract: Under the background of quality education, new requirements are put forward for the training of talents in the new era. Under this background, colleges and universities should deepen the requirements of quality education, and building a curriculum ideological and political education system is of great significance to the training of professional talents in colleges and universities. At present, the educational philosophy of curriculum ideology and politics has gradually been applied and promoted. In practice, it has been verified that this teaching philosophy has an important role and is of great significance for promoting the comprehensive quality training of college talents. However, in the specific curriculum ideological and political practice, there are also some problems. In this regard, this article takes the college music theory basic general curriculum as an example to introduce the necessity of the curriculum ideological and political construction, and analyzes the current general college music theory basic general education The current situation and problems of the teaching reform of knowledge courses, and the effective countermeasures for the reform of the ideological and political construction of the general course of basic music theory in colleges and universities.

Keywords: Curriculum Ideological and Political; Colleges and Universities; Basic Music Theory General Course; Teaching; Reform

The Basic Music Theory General Course is a professional and systematic course, and it is also one of the favorite elective courses for non-music majors in many universities. The related music theory and its practice are themselves very good quality education materials. The promotion of ideological and political construction in this course has a certain foundation and feasibility. However, there are also some outstanding problems in the ideological and political construction of general music theory courses in colleges and universities, which are unfavorable for the teaching reform and development of the course, and timely measures are needed to solve them ${ }^{[1]}$.

\section{The necessity of the ideological and political construction of the general course of basic music theory in colleges and universities}

\subsection{It is an inevitable requirement for the implementation of education policies in the new era}

At the National Education Conference, General Secretary Xi Jinping emphasized: Adhere to the development path of socialist education with Chinese characteristics, and cultivate socialist builders and successors with comprehensive development of moral, intellectual, physical, and artistic. Under the new situation, the faculty and staff of music majors in colleges and universities earnestly study, understand and implement the spirit of General Secretary Xi Jinping's important speech, and carry out the ideological and political construction of general courses on the basics of music theory in colleges and universities. This is the fundamental task of deepening the "ethics and cultivating people". An important measure closely integrated with school career development. In the specific curriculum ideological and political construction, combining

Copyright $(2020$ Yixian Jiang

doi: 10.18686/ahe.v4i10.2894

This is an open-access article distributed under the terms of the Creative Commons Attribution Non-Commercial License (http://creativecommons. org/licenses/by-nc/4.0/), which permits unrestricted non-commercial use, distribution, and reproduction in any medium, provided the original work is properly cited. 
the characteristics of the college's professional teaching, sticking to the main education position of professional classroom teaching, it can also organically integrate "teaching" and "education" in professional classrooms, and continuously promote the classroom teaching of curriculum ideological and political Link reform ${ }^{[2]}$.

\subsection{It is an inevitable requirement for music quality education in colleges and universities}

What colleges and universities cultivate for the society are high-quality talents with certain scientific literacy, good quality, and professional knowledge and skills. Music educating people "moisturizes things silently". In the teaching of basic general courses of music theory in colleges and universities, deepening the ideological and political construction of the curriculum and combining ideological and political and music courses are important measures for colleges and universities to practice quality education. On the one hand, this can promote the improvement of the comprehensive quality of talents, on the other hand, it is also conducive to promoting the development of college education and improving the quality of college education.

\section{The status quo and problems of ideological and political construction in general courses of music theory foundation in colleges and universities}

\subsection{Insufficient emphasis on ideological and political courses, and relatively lagging construction}

At present, in the teaching of basic general courses of music theory in colleges and universities, teachers are not very aware of curriculum ideological and political construction and reform. They are obsessed with the teaching of professional knowledge, and lack attention to curriculum ideological and political construction. As an important reform direction, ideological and political construction has led to more attention to students' professional knowledge mastery in actual curriculum construction, and ignorance of students' ideological and political education. This leads to the relatively lagging of the curriculum ideological and political construction, and the overall curriculum ideological and political construction is not effective, which seriously affects the level of curriculum ideological and political construction.

\subsection{Single teaching method, lack of novelty and creativity}

In the ideological and political construction of general music theory courses in some colleges and universities, teachers also try to carry out ideological and political education in the courses, but the methods and forms adopted are relatively simple, and the integration of some ideological and political content is relatively rigid, and students are not accepting this. High, the teaching effect of ideological and political courses cannot be guaranteed ${ }^{[3]}$. In carrying out the teaching of basic general courses of music theory in colleges and universities, teachers may suggest that everyone should have patriotism, be loyal citizens of the People's Republic of China, and be united when guiding students to learn some patriotic songs. However, the ideological and political teaching of such courses is not new and lacks creativity. It is difficult to attract the attention of students, cannot stimulate students' interest and enthusiasm, and will affect the teaching effectiveness of the course to a certain extent.

\section{Countermeasures for the teaching reform of the general course of basic music theory in colleges and universities from the perspective of "curriculum ideological and political"}

\subsection{Enhance the importance of curriculum ideological and political construction, and promote the acceleration of curriculum ideological and political construction}

To carry out general course teaching of basic music theory in colleges and universities, teachers should increase the importance of curriculum ideological and political construction, and make it clear that the current curriculum ideological and political construction is an important direction of professional curriculum teaching reform, so as to strengthen curriculum ideological and political construction in specific practice and promote Teachers actively promote curriculum ideology and politics in curriculum teaching, and promote the development of general education of basic music theory in colleges and universities. In this regard, on the one hand, colleges and universities need to pay attention to the curriculum ideological and political construction as one of the important teaching tasks of professional teachers, establish curriculum ideological and political teaching reform goals, and require professional teachers to improve ideological and political education in a corresponding time frame. Work to ensure the continuous improvement of the quality of curriculum ideological and political construction. On the other hand, professional teachers should also take curriculum ideological and political construction as one of the main goals of their own curriculum teaching reforms, actively explore the ideological and political teaching factors in the curriculum, and effectively connect professional courses and ideological and political teaching to achieve infiltration teaching. Really moisturize things silently.

\subsection{Innovate the teaching methods of courses and realize the penetration of ideological and political teaching of courses}

In the new era, to carry out the ideological and political teaching of the basic general courses of music theory in colleges 
and universities, it is necessary to innovate the curriculum teaching methods in the actual teaching, change the traditional single course teaching mode, pay attention to the cooperation and discussion in the teaching, and let the curriculum ideological and political infiltrate In the professional course teaching, promote the continuous improvement of the teaching quality and effectiveness of the general course of music theory in colleges and universities. For example, in the teaching of "Music "Language" in the basic general course of music theory, the concept of "ideological politics + music" is used to carry out practical teaching. In class, teachers can first introduce the theme song "Red Detachment of Women" from the movie "Red Detachment of Women", introduce the film works and the revolutionary deeds it reflects to students, and then introduce the musical elements contained in the music. Then use "The March of Volunteers" to explain the melody of the music; use "The Day Out to Be Happy" to explain the rhythm of the music; use the guqin song "Guan Shan Yue", the tune "Man Jiang Hong" to explain the tone and so on. For another example, in the lecture on "mode tonality", you can first introduce the theme song "One Day" from the movie "The Great Cause of Party Building" to guide students to think about the ideological content contained in the lyrics; then explain the class basis and ideological basis of the establishment of the Chinese Communist Party In the second half of the course, the song "Red Boat in South Lake" was played, which closely integrated the teaching content of the founding and meaning of the Communist Party of China, and concluded that the original intention of the Communist Party of China was "to seek happiness for the Chinese people and the scientific conclusion of seeking the revival of the Chinese nation. In the end, the course ended with the inspiring song "Don't Forget Your Original Heart". In the classroom, teachers can also divide students into several groups to carry out heuristic and discussion-style teaching.

Under the background of quality education, the teaching reform of the theoretical basis of music in colleges and universities should closely integrate the background of the times, professional characteristics and student characteristics. By integrating the music works created by teachers, students, and alumni into classroom teaching, sharing creative experience, online teaching work briefings in the college China publishes articles on ideological and political experience in courses, and can also organize students studying music to arrange repertoires and dance clips based on anti-epidemic theme music, actively promote the ideological and political construction of courses, and earnestly implement the fundamental task of Lide Shuren. For example, in the context of the new crown pneumonia epidemic, teachers can integrate curriculum ideological and political teaching work closely with reality, allow students to discuss anti-epidemic songs, share learning experiences, and resonate student values. Combining with the explanation of anti-epidemic stories, guide students to perceive the emotions expressed by anti-epidemic songs, convey the voice with emotion and emotion, let students understand the whole process of song writing, harmony arrangement, interpretation, playing and singing, and deeply understand the influence of music motivation on songs the importance of performance. While explaining the performance technique, the content of the characters and musical connotations of the works are injected to guide students to understand the heroic deeds of the revolutionary martyrs and feel the patriotism expressed in the works. Through the organization and development of diversified curriculum ideological and political teaching activities, guide students to participate in it, feel and appreciate the significance of curriculum ideological and political construction, promote the development of ideological and political teaching of general music theory courses in colleges and universities, and enhance the professional quality of music majors And ideological and political literacy.

\section{Conclusion}

Under the background of curriculum ideological and political construction, the teaching reform of general courses of basic music theory in colleges and universities also needs to actively respond to the call of curriculum ideological and political construction, increase the importance of professional curriculum ideological and political construction, and in the teaching practice of curriculum ideological and political, Innovate concepts and methods to promote the continuous improvement of the effectiveness of curriculum ideological and political construction.

\section{References}

1. Ou J. Integrate ideological and political quality education into the music curriculum in colleges and universities to develop a new music teaching model. Farm Staff 2020; (16): 173.

2. Song Z. A preliminary study on the construction method of "curriculum ideology and politics" in the teaching of specialized courses in colleges and universities_- Taking the music classroom as an example. The Voice of the Yellow River 2019; (22): 64.

3. Chen C. Exploration of innovative teaching mode integrating ideological and political quality education in public music courses in colleges and universities. Journal of Xiangnan University 2019; 40(04): 123-125. 